
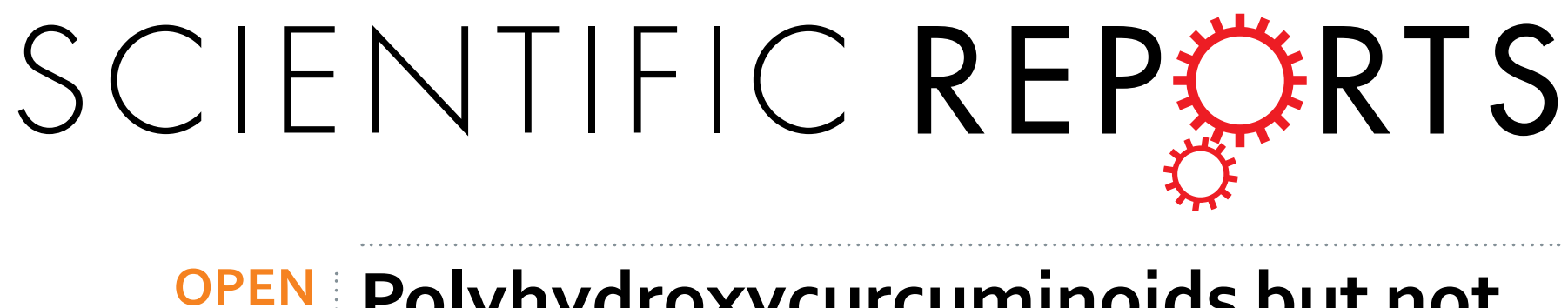

\title{
Polyhydroxycurcuminoids but not curcumin upregulate neprilysin and can be applied to the prevention of Alzheimer's disease
}

Received: 14 July 2015

Accepted: 20 June 2016

Published: 13 July 2016

\author{
Po-Ting Chen ${ }^{1,2}$, Zih-ten Chen², Wen-Chi Hou ${ }^{3}$, Lung-Chih Yu ${ }^{1}$ \& Rita P.-Y. Chen ${ }^{1,2}$
}

Neprilysin (NEP) is the most important A $\beta$-degrading enzyme. Its expression level decreases with age and inversely correlated with amyloid accumulation, suggesting its correlation with the late-onset of Alzheimer's disease. Recently, many reports showed that upregulating NEP level is a promising strategy in the prevention and therapy of Alzheimer's disease. Here, we used a sensitive fluorescencebased $A \beta$ digestion assay to screen 25 curcumin analogs for their ability to upregulate NEP activity. To our surprise, four compounds, dihydroxylated curcumin, monohydroxylated demethoxycurcumin, and mono- and di-hydroxylated bisdemethoxycurcumin, increased NEP activity, while curcumin did not. The ability of these polyhydroxycurcuminoids to upregulate NEP was further confirmed by mRNA and protein expression levels in the cell and mouse models. Finally, feeding monohydroxylated demethoxycurcumin (also named demethylcurcumin) or dihydroxylated bisdemethoxycurcumin (also named bisdemethylcurcumin) to $A_{P P} P_{s w e} / P_{1} d_{1}$ double transgenic mice upregulated NEP levels in the brain and reduced $A \beta$ accumulation in the hippocampus and cortex. These polyhydroxycurcuminoids offer hope in the prevention of Alzheimer's disease.

Age-related Alzheimer's disease (AD), the most common form of dementia, is characterized by the presence of intracellular neurofibrillary tangles and extracellular senile plaques. The senile plaques are mainly composed of amyloid- $\beta$ peptides $(\mathrm{A} \beta)$, which are 39-43 amino acid peptides. According to the amyloid cascade hypothesis, the excessive accumulation and abnormal aggregation of $A \beta$ is linked to the onset of the neurodegenerative process. Recent success in the clinical trial of passive anti-A $\beta$ immunotherapy such as Aducanumab on reducing $A \beta$ accumulation and slowing cognitive decline in prodromal and mild AD patients suggested that $\mathrm{A} \beta$ clearance is a promising strategy in $\mathrm{AD}$ prevention and therapy ${ }^{1,2}$.

A $\beta$ levels are a dynamic equilibrium between production and clearance. Under normal physiological condition, $A \beta$ can be degraded by several endogenous endopeptidases including neprilysin (NEP), plasmin, insulin-degrading enzyme (IDE), endothelin-converting enzyme, angiotensin-converting enzyme (ACE), and several matrix metalloproteases ${ }^{3}$. NEP has been singled out as the most promising target because (1) its protein levels are lower in AD brains than normal brains ${ }^{4}$ and are inversely correlated with age ${ }^{5}$; (2) NEP mRNA levels are lower in high plaque density regions of human $\mathrm{AD}$ brains than in other regions or the corresponding regions of normal brains ${ }^{6}$; (3) NEP activity and protein levels in the hippocampus decline with age in mice ${ }^{7}$; (4) NEP protein levels are higher in the cerebellum of mice than in the cortex and hippocampus, regions of major $A \beta$ plaque accumulation ${ }^{7,8}$; and (5) A $\beta$ levels are twice as high in NEP knock out mice ${ }^{3,9}$. It has been reported that peripheral overexpression of NEP in muscle ${ }^{10}$ or leukocytes ${ }^{11}$, direct injection of NEP protein into the brain ${ }^{12}$, or overexpression NEP in the brain of AD transgenic mice ${ }^{13-15}$ reduced amyloid load in the mouse brain and improved cognitive ability. These data strongly link NEP activity with amyloid accumulation in AD pathogenesis. Since NEP expression declines with age ${ }^{5}$, restoring NEP activity to its normal level or maintaining its normal level would be beneficial in restoring or maintaining homeostasis of $A \beta$ production and degradation and could serve as a feasible approach for $\mathrm{AD}$ prevention.

\footnotetext{
${ }^{1}$ Institute of Biochemical Sciences, National Taiwan University, No. 1, Sec. 4, Roosevelt Rd., Taipei 106, Taiwan. ${ }^{2}$ Institute of Biological Chemistry, Academia Sinica, No. 128, Sec. 2, Academia Rd., Nankang, Taipei 115, Taiwan. ${ }^{3}$ Graduate Institute of Pharmacognosy, Taipei Medical University, No. 250, Wuxing St., Taipei 110, Taiwan. Correspondence and requests for materials should be addressed to R.P.-Y.C. (email: pyc@gate.sinica.edu.tw)
} 
Certain medicinal plants are thought to be effective in improving brain function, and secondary metabolites in plants have been extensively examined as possible AD therapeutic reagents. Ayoub and Melzig found that apigenin, luteolin, and curcumin increased both ACE and NEP activity and rolipram increased only NEP activity in human SK-N-SH neuroblastoma cells ${ }^{16}$. Eisele et al. reported that Gleevec (a tyrosine kinase inhibitor) treatment increased NEP protein and mRNA levels in human APP transfected H4 human neuroglioma cells ${ }^{17}$. Klein et al. reported that kynurenic acid (a tryptophan catabolite) induced NEP protein and mRNA levels and also NEP activity in human SH-SY5Y neuroblastoma cells ${ }^{18}$. AD incidence surveys have reported that the incidence of $\mathrm{AD}$ in an Indian population was almost 5 times lower than that in a US population ${ }^{19,20}$. Turmeric is widely used as a food additive (curry spice) and as a traditional medicine in Asia, particular in India. Since diet is one of the causative factors for $\mathrm{AD}$, these surveys stimulated many studies exploring the effect of curcumin or curcuminoids (the major effective components in turmeric) and their possible application in AD therapy ${ }^{21}$. Curcuminoids are a mixture of bisdemethoxycurcumin (3-5\%), demethoxycurcumin (15-20\%), and curcumin (75-80\%) ${ }^{22}$. Liao et al. ${ }^{23}$ showed that curcuminoids promote neurite outgrowth in PC12 cells. Lim et al. ${ }^{24}$ fed curcumin to an AD transgenic mouse model (Tg2576) for 6 months and found that low-dose curcumin treatment (160 ppm; 32 mg/ $\mathrm{kg} /$ day) reduced $\mathrm{A} \beta$ content and plaque burden in the brain, while high-dose treatment $(5000 \mathrm{ppm} ; \sim 990 \mathrm{mg} / \mathrm{kg} /$ day) had no effect. Wang et al. ${ }^{25}$ showed that feeding a high dose of curcumin $(200 \mathrm{mg} / \mathrm{kg} / \mathrm{day})$ to an AD double transgenic mouse model $\left(\mathrm{APP}_{\text {swe }} / \mathrm{PS}_{1} \mathrm{dE}_{9}\right)$ for 3 months reduced $\mathrm{A} \beta$ levels and increased NEP and IDE expression in the hippocampus and improved spatial learning and memory ability. Ahmed et al.$^{26}$ reported that intraperitoneally injected curcuminoids enhanced memory in amyloid-infused rats; interestingly, in their study, bisdemethoxycurcumin and demethoxycurcumin were more effective than curcumin. It has been known that curcumin has very poor solubility and bioavailability and demethoxylation could improve solubility ${ }^{27}$. Curcumin analogs with better bioavailability might have better efficacy. We hypothesize that turmeric might have beneficial effect on maintaining the balance between anabolism and catabolism of A $\beta$ by upregulating NEP and other curcumin analogs in turmeric might be more beneficial than curcumin.

\section{Results}

Screen of curcumin analogs on upregulation of NEP by activity assay. We first compared the ability of curcumin and 25 curcumin analogs to enhance NEP activity using human SH-SY5Y cells; the structures of these compounds are shown in Fig. 1. In this activity assay, we measured the fluorescence increase caused by cleavage of a quenched fluorogenic peptide, qf-A $\beta(1-7) \mathrm{C}$, which can be cleaved by NEP and IDE, but not by other A $\beta$-degrading enzymes (Fig. 2a) ${ }^{28}$. Since NEP is an ectoenzyme, after the cells were treated with compounds, the compounds were removed by replacing the cell medium with the assay buffer containing qf-A $\beta(1-7) \mathrm{C}$ which can be degraded by NEP on cell surface. The fluorescence intensity in the assay buffer was measured. The results showed that compounds 7 (monohydroxylated demethoxycurcumin, also named demethylcurcumin), 8 (dihydroxylated bisdemethoxycurcumin, also named bisdemethylcurcumin), 10 (dihydroxylated curcumin), and 20 (monohydroxylated bisdemethoxycurcumin, also named demethylmonodemethoxycurcumin) enhanced fluorescence intensity whereas curcumin did not (Fig. 2b) and that the fluorescence increase, using compound 8 as an example, was dose-dependent (Fig. 2c). Comparison of the results for compound 1(curcumin; with 2 methoxy groups), compound 3 (bisdemethoxycurcumin; without methoxy group), compound 9 (with 4 methoxy groups), and compound 18 (demethoxycurcumin; with one methoxy group) showed that the number of methoxy groups is not relevant to their efficacy on upregulating NEP activity in SH-SY5Y cells. Comparing the structures of four effective compounds examined (compound $7,8,10,20$ ) with the others, we found that the effective compounds have at least three hydroxyl groups (three for compounds 7 and 20 and four for compounds 8 and 10) on the 1,7-bisphenyl-1,6-heptadiene-3,5-dione scaffold. We therefore propose that the number of hydroxyl groups on curcumin analogs is critical in efficacy of NEP upregulation.

Compounds 7, 8, 10, 20 upregulate NEP rather than other $A \beta$-degrading enzymes. Since qf-A $\beta(1-7) C$ can be cleaved by both NEP and IDE $^{28}$, whether the enhanced fluorescence intensity indeed came from the reaction of NEP or IDE was examined by using another substrate-specific peptide substrate. The peptide, qf-A $\beta(12-16) A A C$, which can be cleaved by ACE and NEP, but not other A $\beta$-degrading enzymes ${ }^{29}$, was used to test the effects of compounds 1, 7, 8, 10, and 20. As shown in Fig. 3a, compounds 7, 8, 10, and 20 caused increased activity, suggesting that these four compounds activate NEP, and not IDE. This conclusion was confirmed in the case of compound 8 using thiorphan, an NEP-specific inhibitor (Fig. 3b). After incubating SH-SY5Y cells with or without compound 8 for $12 \mathrm{~h}$, the cell medium was replaced with $400 \mu \mathrm{L}$ of assay buffer alone or containing $50 \mu \mathrm{M}$ thiorphan for $30 \mathrm{~min}$ prior to addition of qf-A $\beta(12-16) \mathrm{AAC}$, and thiorphan was found to decrease substrate cleavage activity to about $20 \%$ of the untreated control, both in the absence or presence of compound 8 , demonstrating that most of the increased activity induced by compound 8 was due to an effect on NEP. Moreover, we examined the NEP protein level in the membrane fraction of the differentiated SH-SY5Y cells without or with treatment of curcumin, compound 7, or compound 8 by western blotting. Compounds 7 and 8 significantly increased NEP protein (Fig. 4).

Compounds $7 \& 8$ increase NEP mRNA levels in the mouse brain. To examine whether compound 7 \& 8 can pass blood-brain-barrier and function in the brain, we fed curcumin or compound 7 or 8 to normal B6C3 mice $(10 \mathrm{mg} / \mathrm{kg} \mathrm{BW})$ every day for 7 days. The total NEP mRNA level in the brain was quantitated by real-time PCR. The results showed that feeding compound 7 or 8 increased NEP mRNA level in the mouse brain, whereas feeding with curcumin did not yield the same effect (Fig. 5).

Compound 7 upregulates NEP and decreases $A \beta$ accumulation in the hippocampus and cortex of the AD double transgenic mice $A P P_{s w e} / P S_{1} d$. Compound 7 is a minor component of turmeric, i.e. 


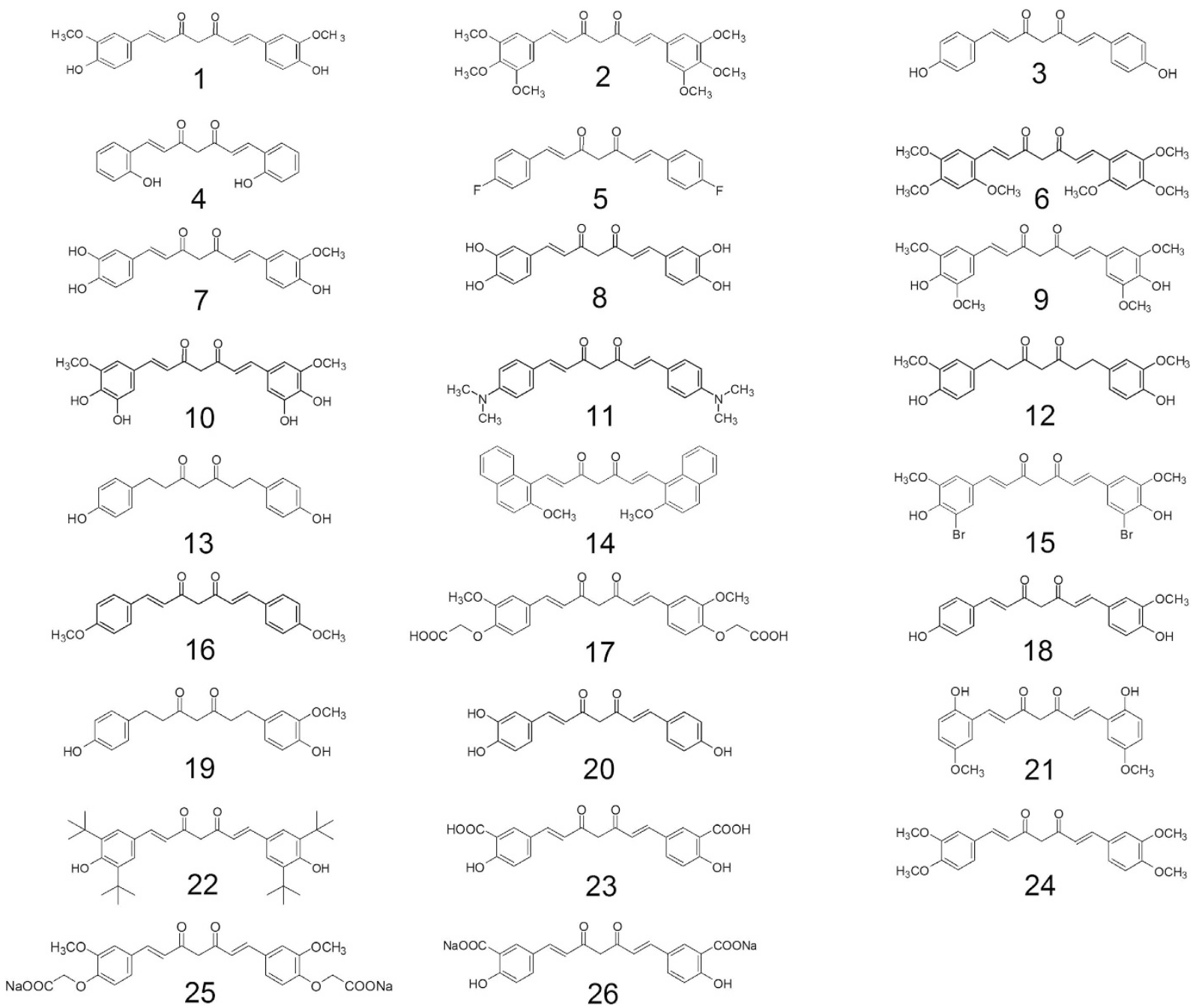

Figure 1. Structures of curcumin (compound 1) and 25 curcumin analogs (compound 2-26). 1, 1,7-Bis(4hydroxy-3-methoxyphenyl)-1,6-heptadiene-3,5-dione); 2, 1,7-Bis(3,4,5-trimethoxyphenyl)-1,6-heptadiene3,5-dione; 3, 1,7-Bis(4-hydroxyphenyl)-1,6-heptadiene-3,5-dione; 4, 1,7-Bis(2-hydroxyphenyl)-1,6-heptadiene3,5-dione; 5, 1,7-Bis(4-fluorophenyl)-1,6-heptadiene-3,5-dione; 6, 1,7-Bis(2,4,5-trimethoxyphenyl)-1,6heptadiene-3,5-dione; 7, 1-(3,4-Dihydroxyphenyl)-7-(3-methoxy-4-hydroxyphenyl)-1,6-heptadiene-3,5-dione; 8, 1,7-Bis(3,4-dihydroxyphenyl)-1,6-heptadiene-3,5-dione; 9, 1,7-Bis(4-hydroxy-3,5-dimethoxyphenyl)1,6-heptadiene-3,5-dione; 10, 1,7-Bis(3,4-dihydroxy-5-methoxyphenyl)-1,6-heptadiene-3,5-dione; 11, 1,7-Bis(4-N,N-dimethylaminophenyl)-1,6-heptadiene-3,5-dione; 12, 1,7-Bis(4-hydroxy-3-methoxyphenyl) heptan-3,5-dione; 13, 1,7-Bis(4-hydroxyphenyl)heptan-3,5-dione; 14, 1,7-Bis(2-methoxy-1-naphthyl)-1,6heptadiene-3,5-dione; 15, 1,7-Bis(3-bromo-4-hydroxy-5-methoxyphenyl)-1,6-heptadiene-3,5-dione; 16, 1,7-Bis(4-methoxyphenyl)-1,6-heptadiene-3,5-dione; 17, 1,7-Bis(3-methoxy-4-carboxymethoxyphenyl)-1,6heptadiene-3,5-dione; 18, 1-(4-Hydroxyphenyl)-7-(4-hydroxy-3-methoxyphenyl)-1,6-heptadiene-3,5-dione; 19, 1-(4-Hydroxyphenyl)-7-(4-hydroxy-3-methoxyphenyl)-heptan-3,5-dione; 20, 1-(3,4-Dihydroxyphenyl)7-(4-hydroxyphenyl)-1,6-heptadiene-3,5-dione; 21, 1,7-Bis(2-hydroxy-5-methoxyphenyl)-1,6-heptadiene3,5-dione; 22, 1,7-Bis(3,5-di-tert-butyl-4-hydroxyphenyl)-1,6-heptadiene-3,5-dione; 23, 1,7-bis(3-carboxy-4hydroxyphenyl)-1,6-heptadiene-3,5-dione; 24, 1,7-Bis(3,4-dimethoxyphenyl)-1,6-heptadiene-3,5-dione; 25, 1,7-Bis(4-carboxymethoxy-3-methoxyphenyl)-1,6-heptadiene-3,5-dione disodium salt; 26, 1,7-bis(3-carboxy4-hydroxyphenyl)-1,6-heptadiene-3,5-dione disodium salt.

a natural compound ${ }^{30}$ and has been reported with a higher antioxidative effect than curcumin by inhibiting lipid peroxidation and protein oxidation in rat liver mitochondria ${ }^{31}$. It was therefore tested for efficacy in $\mathrm{A} \beta$ clearance in double transgenic $\mathrm{APP}_{\text {swe }} / \mathrm{PS}_{1} \mathrm{dE}_{9}$ mice. Mice aged 4.5-5.5 months were fed compound 7 (10 mg/kg BW) or vehicle by gavage six times a week at a much lower dose than that of curcumin used in previous studies ${ }^{24,25,32,33}$. After feeding for 6.5 months, the mice were sacrificed, and then NEP mRNA levels in the hippocampus and cortex were quantitated by real-time PCR (Fig. 6a). It is clear that NEP mRNA level in the hippocampus was lower than that in the cortex of the untreated mice. After treating with compound 7, a significant increase could be seen in the hippocampus with a slight increase in the cortex. The western blotting data in Fig. $6 \mathrm{~b}$ also showed that the NEP protein amount in the cortex was higher in the mice fed with compound 7 than in the mice fed with vehicle. 
(a)

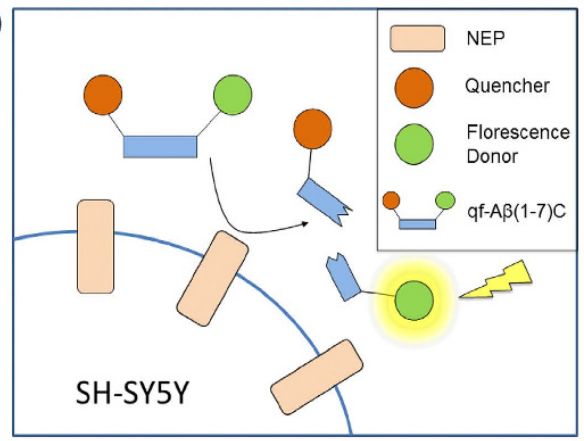

(c)

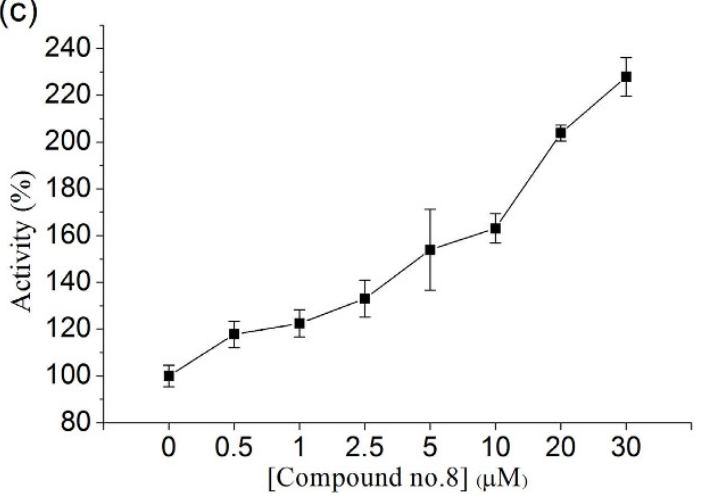

(b)

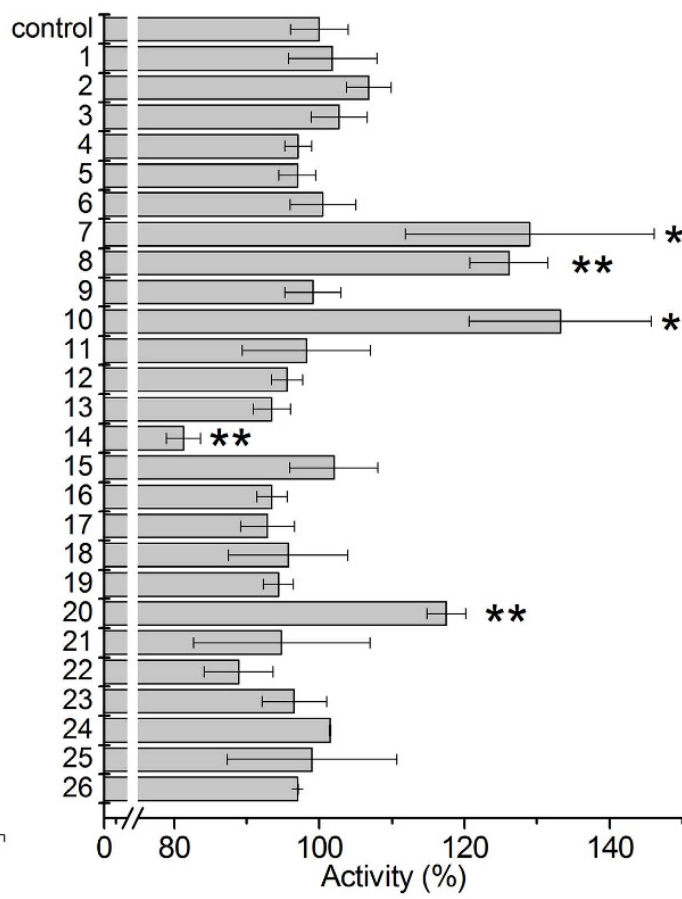

Figure 2. Screen compounds with the ability to increase $\mathbf{A} \beta$-degradation. (a) $A \beta$-degrading activity assay using qf-A $\beta(1-7) \mathrm{C}$ as substrate. (b) Results for SH-SY5Y cells incubated for $24 \mathrm{~h}$ with $0.5 \%$ DMSO (control) or the compound listed on the y axis $(5 \mu \mathrm{M})$. (c) A 3 -degrading activity assay using different concentrations of compound 8. In $(\mathbf{b}, \mathbf{c})$, the data are presented as the mean \pm SD for three independent samples; in $(\mathbf{b}){ }^{*} \mathrm{p}<0.05$; $* * \mathrm{p}<0.01$ compared to the control by one-way ANOVA.

As a consequence, compound 7 feeding should be able to decrease $A \beta$ accumulation in the brain. The $A \beta$ amounts were analyzed by ELISA. The compound 7-treated mice had a significant decrease in formic acid-extracted insoluble A 340 (top panel) and A 342 (bottom panel) in the cortex and hippocampus (Fig. 6c).

Compound 8 reduced $A \beta$ plaque load in the brain of the AD double transgenic mice APP $P_{\text {swe }} /$ $\mathrm{PS}_{1} \mathrm{dE}_{9}$. $\quad$ Mice aged 3 months were fed compound $8(10 \mathrm{mg} / \mathrm{kg} \mathrm{BW})$ or vehicle by gavage six times a week for 8 months. The amyloid plaque accumulation was then evaluated by ThS staining (Fig. 7). The amyloid plaque number in the compound 8 -treated transgenic mice was reduced by $28 \%$ in the cortex and $44 \%$ in the hippocampus. The plaque-covered area was reduced by $25 \%$ in the cortex and $43 \%$ in the hippocampus. The data indicated that feeding compound 8 was effective in decreasing plaque burden in the brain, especially in the hippocampus. This observation aligns with our NEP mRNA quantification results in Fig. 5. Compound 8 can increase NEP mRNA level. It has been reported that the hippocampus has the lowest NEP expression compared with other regions in the brain of mouse and human ${ }^{7,34}$. NEP expression might be under well-regulated control, so its expression cannot increase much to degrade other neuropeptides. Therefore, the upregulation effect of compound 8 is more prominent in the region that has lower NEP expression, i.e. hippocampus, and the amyloid load reduction is greater in the hippocampus than cortex.

Possible mechanism of polyhydroxycurcuminoids-induced NEP upregulation. It has been reported that NEP transcription can be regulated by DNA methylation in a CPG island in its promoter region, and that hypermethylation in this $\mathrm{CpG}$ island is related to decreased NEP expression in various cancers ${ }^{35,36}$. Here, we examined whether polyhydroxycurcuminoids-induced NEP upregulation is achieved via altered NEP DNA methylation status. The $\mathrm{N} 2 \mathrm{a}$ cells were treated with curcumin, compound 7 , or compound 8 , and the methylation of the NEP gene was analyzed by bisulfite genomic sequencing according to the literature ${ }^{37}$. In 10 clones, the percentages of total methylated CpG were 91.3 (control), 92.6 (curcumin), 90.5 (compound 7), and 91.8\% (compound 8 ) (Fig. 8). The NEP gene was heavily methylated in all four groups. Compound 7 and 8 treated cells have slightly more sites (20 sites) with unmethylated cytosine than control (18 sites) and curcumin treated cells (19 sites). When comparing only the high CpG density region (site 23-34), the percentages of total methylated CpG were 92.5 (control), 91.7 (curcumin), 84.2 (compound 7), and 89.2\% (compound 8). The differences were small, except for compound 7 ( $p=0.069$ compared with control by Fisher's exact test). None of the compound-treated groups showed significant difference compared with control. We did not observe a significant change in $\mathrm{CpG}$ demethylation in the curcumin treated group, which was reported by Deng et al. ${ }^{37}$. Compounds 7 - and 8 - treated groups have less methylated $\mathrm{CpG}$ than curcumin-treated but the differences were not statistically significant (see 
(a)

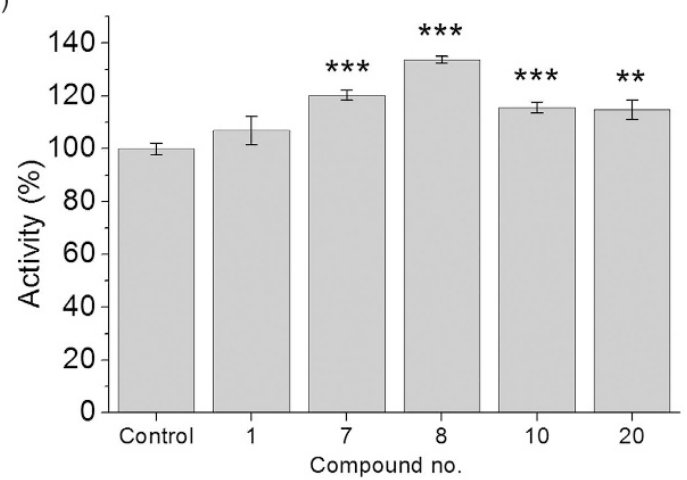

(b)

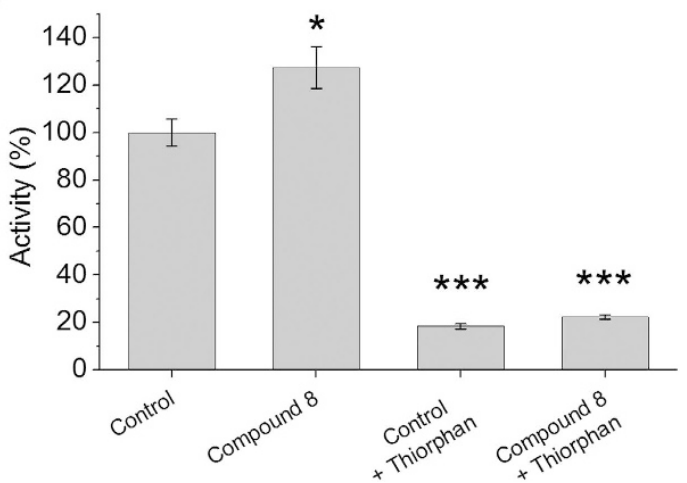

Figure 3. Examination of the increased $A \beta$-degrading activity coming from the action of NEP. (a) $A \beta$ degrading activity assay using qf-A $\beta(12-16)$ AAC as substrate. SH-SY5Y cells were incubated $12 \mathrm{~h}$ with $0.5 \%$ DMSO (control) or the indicated compounds $(5 \mu \mathrm{M})$ before assay. (b) Thiorphan inhibition assay. SH-SY5Y cells were incubated for $12 \mathrm{~h}$ with $0.5 \%$ DMSO or compound $8(5 \mu \mathrm{M})$, then with or without $50 \mu \mathrm{M}$ thiorphan for $30 \mathrm{~min}$ before $\mathrm{A} \beta$-degrading activity was measured. The data are the mean $\pm \mathrm{SD}$ for three independent samples. ${ }^{*} \mathrm{p}<0.05 ; * * \mathrm{p}<0.01 ; * * * \mathrm{p}<0.001$ compared to the control by Student's t-test.

(a)

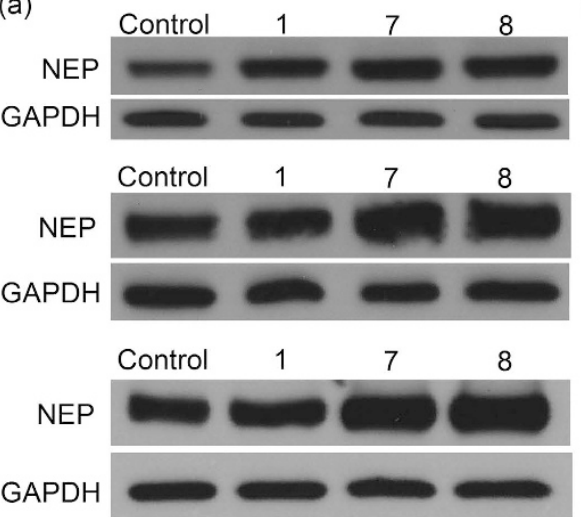

(b)

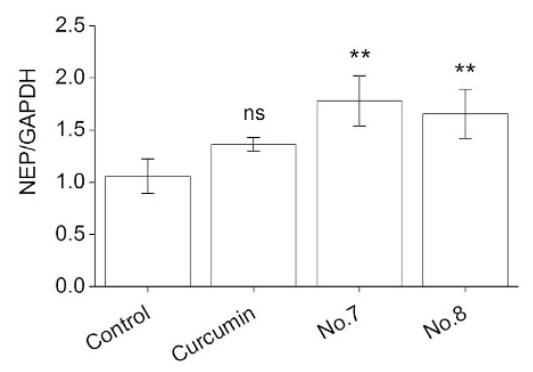

Figure 4. Western blot analysis and quantitative densitometry for NEP levels in RA-differentiated SH-SY5Y cells. The cells were incubated with $0.5 \%$ DMSO (control) or $5 \mu \mathrm{M}$ curcumin (no. 1) or compound 7 or 8 for $24 \mathrm{~h}$, then NEP protein in the cell membrane fraction was measured by western blotting. (a) Western blotting results of three independent experiments. GAPDH was used as the loading control. (b) The quantification of NEP protein levels by Image J. The NEP intensities were normalized to the GAPDH intensities for three independent experiments. Data are presented as the mean $\pm \mathrm{SD}$; ns, not significant; **p $<0.01$ compared to the DMSOtreated control group by Student's t-test.

supplementary information). Based on the data, we can not exclude the possibility that CpG demethylation is involved in the polyhydroxycurcuminoids-induced NEP upregulation, but other mechanisms, such as NEP oxidation $^{4}$, NEP mRNA stability ${ }^{38}$, NEP membrane translocation ${ }^{39}$, might also contribute to the NEP upregulation. 


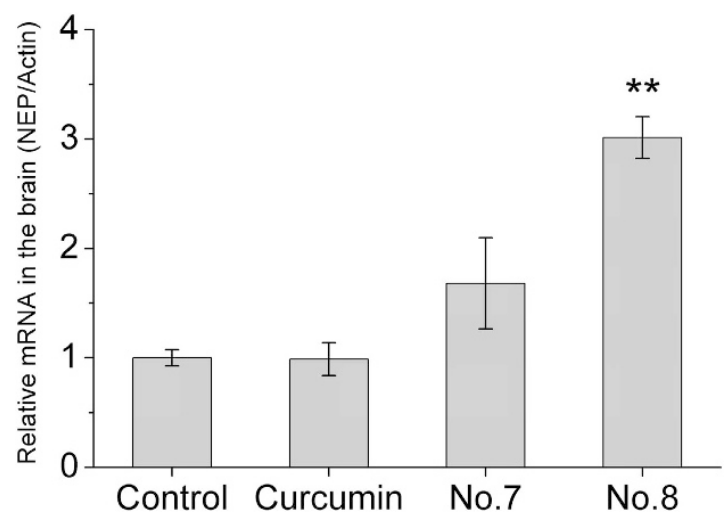

Figure 5. NEP mRNA levels in the brains of mice fed vehicle (control) or the indicated compound for 7 days $(10 \mathrm{mg} / \mathrm{kg} \mathrm{BW}$ per day) by gavage $(\mathbf{n}=5) . \beta$-actin was used as the reference gene. The results are the mean $\pm \mathrm{SEM} ; * * \mathrm{p}<0.01$ compared to the vehicle-fed group by Student's $\mathrm{t}$-test.

(a)

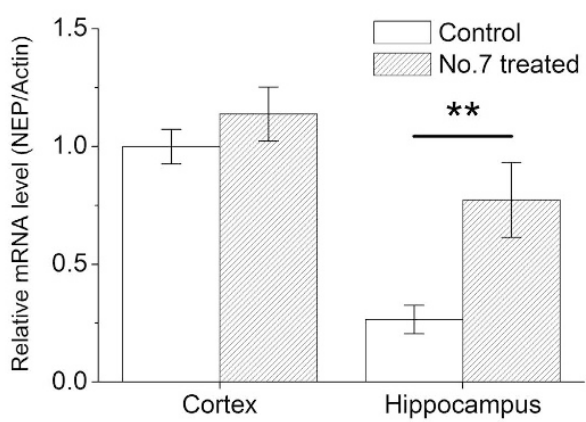

(b)

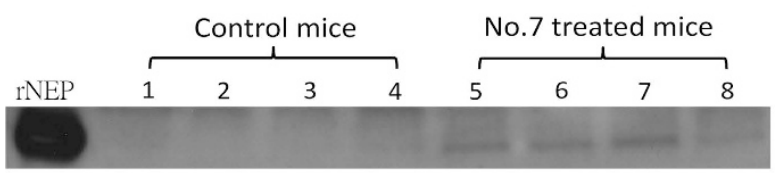

(c)
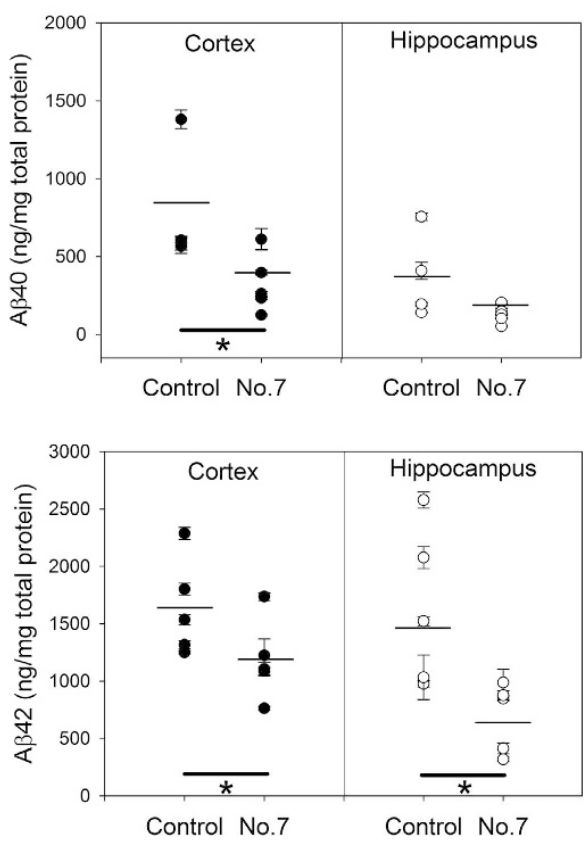

Figure 6. Effect of compound 7 on NEP mRNA and protein levels and $\mathrm{A} \boldsymbol{\beta}$ clearance in vivo. $\mathrm{APP}_{\text {swe }} / \mathrm{PS}_{1} \mathrm{dE}_{9}$ mice were fed vehicle (control) or compound $7(10 \mathrm{mg} / \mathrm{kg}$ BW) six times per week for 6.5 months by gavage. (a) NEP mRNA levels in the cortex and hippocampus using $\beta$-actin as the reference gene, with the value for the cortex of the vehicle-fed control group set as 1 . The results are presented as the mean $\pm \operatorname{SEM}(n=5)$. (b) Neprilysin western blot. Protein samples of $12 \mu \mathrm{g}$ extracted from the hippocampus of eight $\mathrm{APP}_{\text {swe }} / \mathrm{PS}_{1} \mathrm{dE}_{9}$ mice fed with vehicle or compound 7 were resolved on an $8 \%$ Bis-Tris gel and immunoblotted with rat monoclonal anti-mouse NEP antibody. (c) ELISA results for formic acid-extracted (insoluble) A $\beta 40$ (top panel) and A $\beta 42$ (bottom panel) in the cortex and hippocampus; the data for each mouse are indicated and the mean is indicated by the line $(\mathrm{n}=5)$. The heavy black line indicates the sets of data showing a significant difference; $* p<0.05$; $* \mathrm{p}<0.01$ compared to the control by Student's t-test.

\section{Discussion}

Previously, somatostatin, rolipram, luteolin, apigenin, and curcumin was reported showing the ability of increasing NEP activity using activity assay but there was no supporting data showing increase in NEP mRNA or protein levels ${ }^{16,40}$. Using activity assay alone could not exclude the possibility the substrate degradation coming from the action of other proteases. Gleevec and kynurenic acid have been reported with the ability of increasing NEP protein and mRNA levels ${ }^{17,18}$ in the cell models. However, no in vivo data to support that they can upregulate NEP in the brain. In our study, we employed two different activity assays and one NEP inhibitor assay to corroborate that our screened compounds are effective on upregulating NEP but not on other proteases. The assay of mRNA levels in the mouse brain tissues proved that our screened compounds which were delivered orally can 
(a)
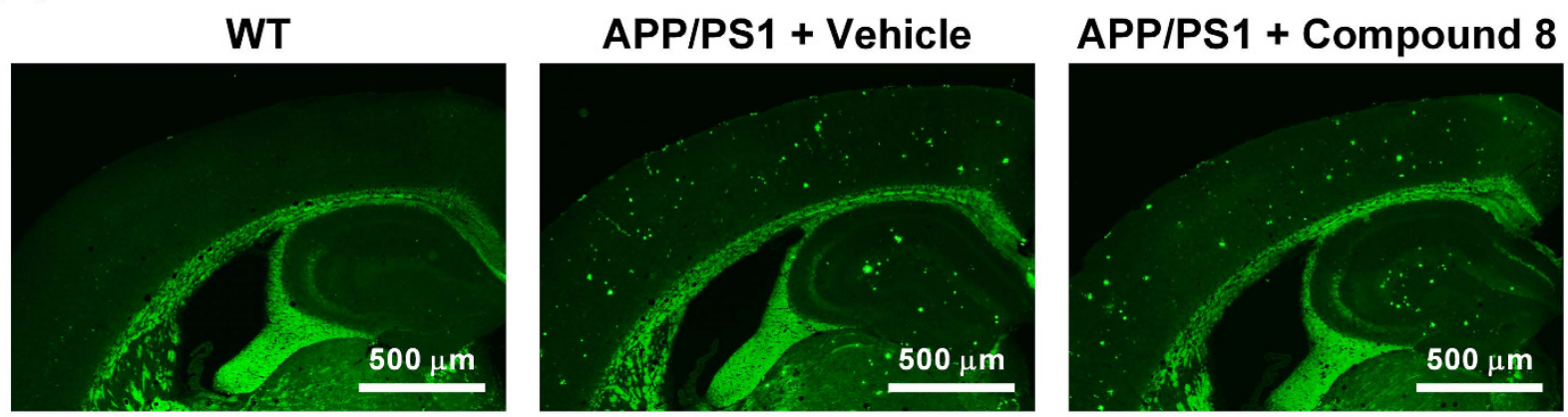

(b) Cortex

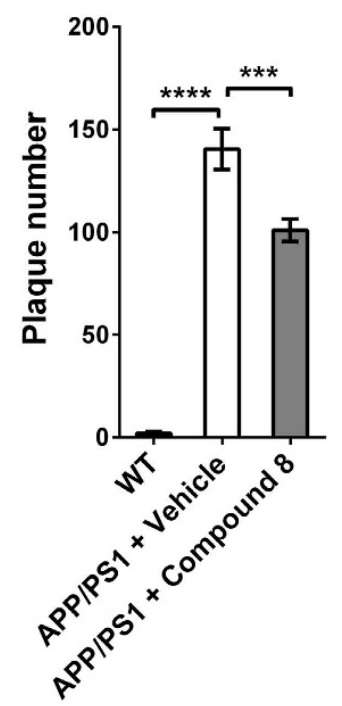

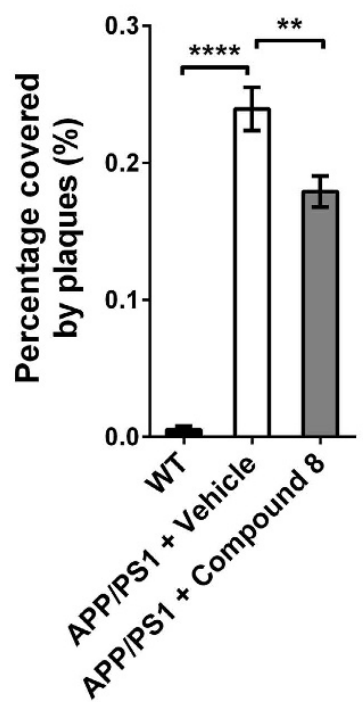

(c) Hippocampus
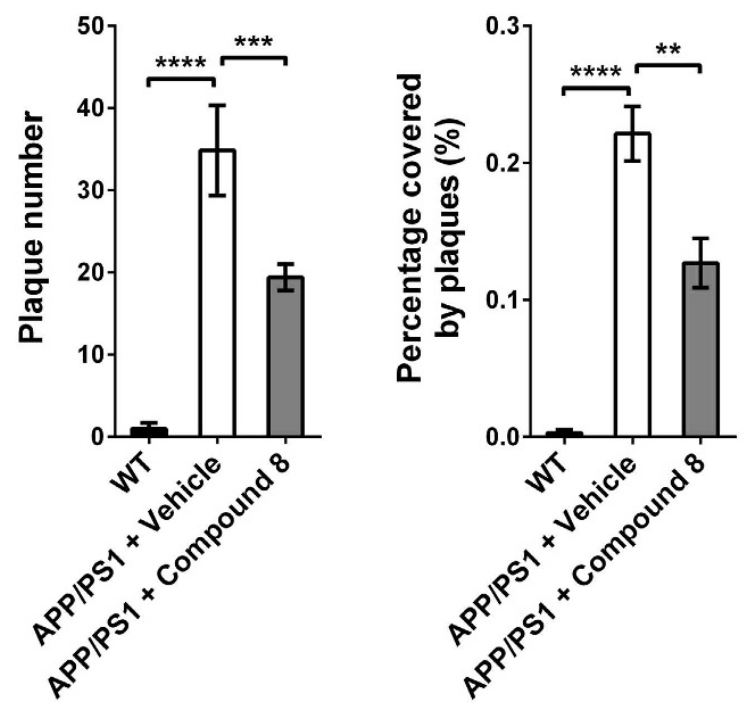

Figure 7. Effect of compound 8 on reducing amyloid plaque burden in the mouse brain. The $\mathrm{APP}_{\text {swe }} /$ $\mathrm{PS}_{1} \mathrm{dE}_{9}$ mice were treated with vehicle or compound 8 for 8 months. Plaque burden of the 11-month-old WT littermate $(n=4)$, vehicle-treated $(n=3)$ and compound 8 -treated transgenic mice $(n=6)$ were analyzed by ThS staining (4 slices per mouse). (a) Representative ThS-staining images. (b,c) Plaque number and percentage of plaque-covered area in the cortex (b) and hippocampus (c) were quantitated by ImageJ. Data was expressed in mean \pm SEM $(* \mathrm{p}<0.05, * * \mathrm{p}<0.01, * * * \mathrm{p}<0.001, * * * * \mathrm{p}<0.0001$ by one-way ANOVA with Fisher's LSD test).

pass blood-brain-barrier to upregulate NEP in the brain. We noted that this upregulation was not dramatic but mild. We surmise that there might be a feedback inhibition mechanism to regulate NEP transcription to avoid big increase in NEP level. The significant difference in NEP mRNA level after our compound 7 treatment occurs in the hippocampus where the mRNA level is much lower than that in the cortex. It has been reported that NEP activity and protein levels in the hippocampus decline with age in mice $^{7,8}$. Increasing NEP level in hippocampus should be very beneficial to rebuild the balance between $A \beta$ production and degradation and avoid $A \beta$ accumulation in the hippocampus where is important for memory.

In this study, curcumin was not found to affect NEP activity, mRNA levels, or protein levels. Other major components in turmeric such as demethoxycurcumin and bisdemethoxycurcumin could not increase NEP activity either. The screened effective curcumin analogs have three or more hydroxyl groups. These polyhydroxycurcuminoids, such as compounds 7 and 20, were found in curcuminoids extracted from rhizomes of Curcuma longa $a^{30,41}$. We propose that the most effective components in turmeric for AD prevention are the hydroxylated curcumin and (bis)demethoxycurcumin (i.e. polyhydroxycurcuminoids), but not the major components curcumin and (bis)demethoxycurcumin. Curcumin is well known with poor solubility and bioavailability. Because these polyhydroxycurcuminoids contain more hydrophilic hydroxyl groups, their solubility and bioavailability should be greater than those of curcumin ${ }^{27}$. Moreover, it has been reported that polyhydroxycurcuminoids have higher antioxidant activity than curcumin and other commercially available antioxidants, such as vitamin C and vitamin $\mathrm{E}^{42,43}$. We conclude that these polyhydroxycurcuminoids are better candidates than curcumin as a dietary supplement in the prevention and therapy of Alzheimer's disease. 

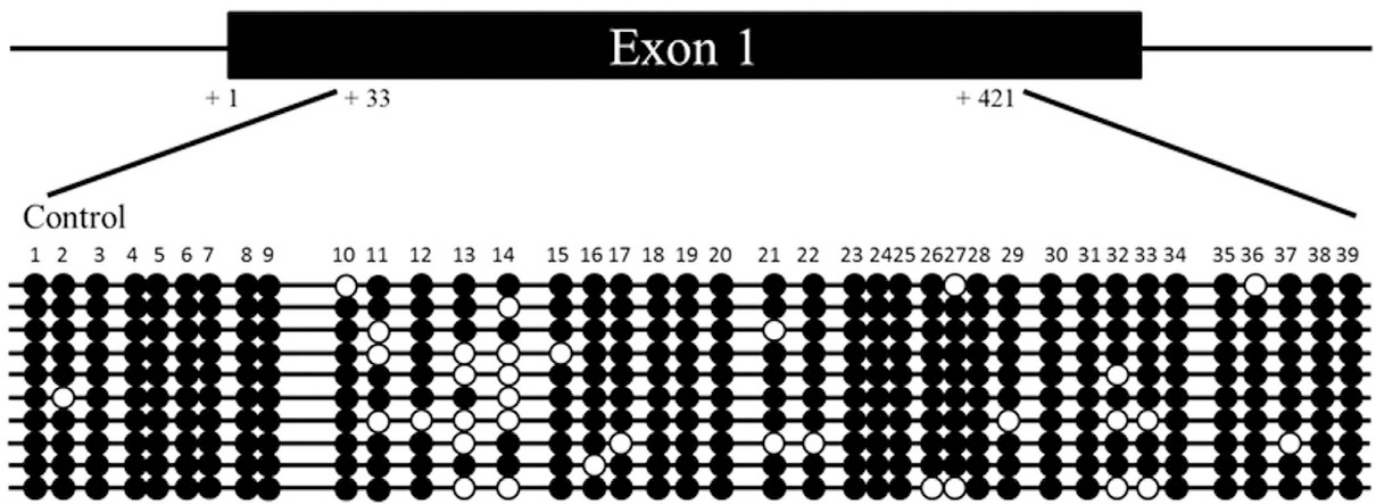

Curcumin

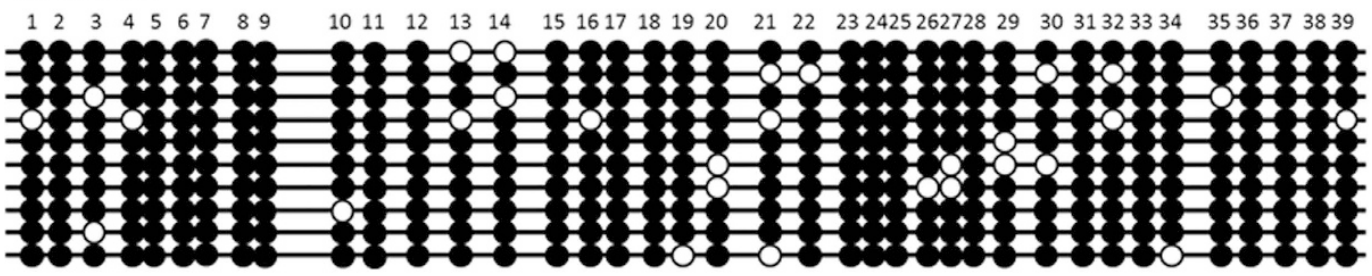

Compound no.7

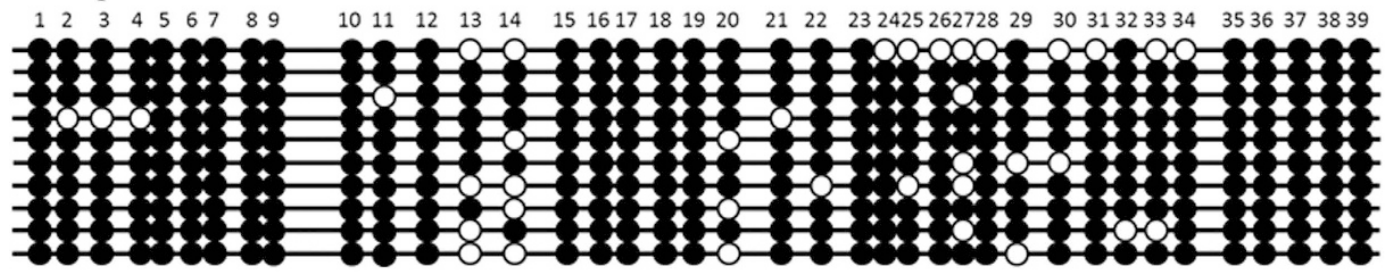

Compound no.8

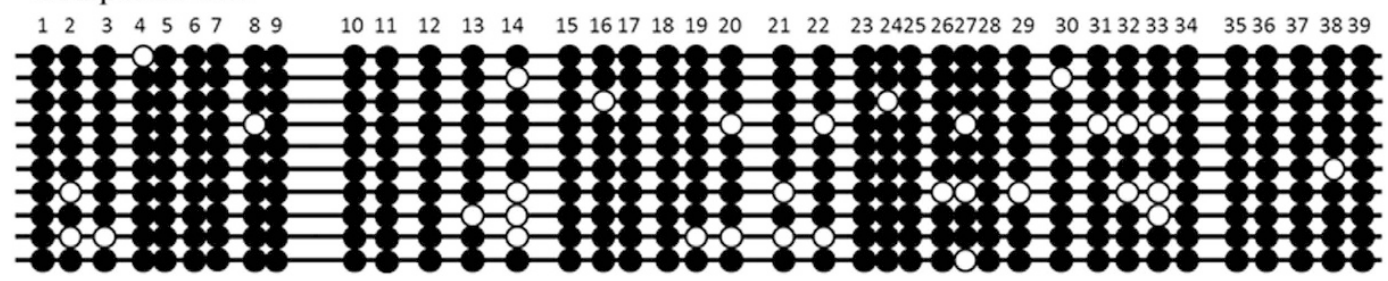

Figure 8. Effects of curcumin and compounds 7 and 8 on DNA methylation of NEP in the N2a cells. The genomic structure of the CpG island in the mouse NEP promoter region is drawn to scale above the bisulfite sequencing chromatogram. The $\mathrm{CpG}$ sites are indicated by number. Each row of circles indicates a single cloned allele. Black circle, methylated cytosine; white circle, unmethylated cytosine.

\section{Methods}

Screened compounds. Curcumin (no.1) and 25 curcumin analogs (no. 2-26) were purchased from Laila Impex Co. (Vijayawada, India) with purity $>99 \%$. The names and structures of these compounds are shown in Fig. 1.

Cell culture. Human neuroblastoma SH-SY5Y cells were purchased from the American Type Culture Collection (ATCC, USA) and cultured in Dulbecco's modified Eagle's medium: Nutrient Mixture F-12 (DMEM/F-12, Life technologies, USA) supplemented with $10 \%$ fetal bovine serum (FBS; Biological industries, USA) in $5 \% \mathrm{CO}_{2}$ at $37^{\circ} \mathrm{C}$.

$\mathbf{A} \beta$-degrading activity assay using qf-A $\beta(1-7) C$ as substrate. Test compounds $1-24$ were dissolved as stock solutions of 1-10 mM in DMSO and compounds 25 and 26 were dissolved as a $1 \mathrm{mM}$ stock solution in distilled water and diluted in medium for use; the vehicle control, DMSO was diluted to the same extent $(0.2-0.5 \%)$. qf-A $\beta(1-7) C$ (sequence DAEFRHDC with Alexa-350 (Alexa Fluor ${ }^{\circledR} 350 \mathrm{C}_{5}$-maleimide, Invitrogen) conjugated to the sidechain of Cys and amine-reactive Dabcyl (4-( $4^{\prime}-\mathrm{N}, \mathrm{N}$-dimethylaminophenyl)azobenzoic acid, succinimidyl ester, Invitrogen) as a quencher linked to the $\mathrm{N}$-terminus of the peptide) was synthesized ${ }^{28}$ and was dissolved in DMSO as a $2 \mathrm{mM}$ stock solution. For screening, 96-well culture plates were used to screen the 26 compounds. SH-SY5Y cells were grown to confluence in $100 \mathrm{~mm}$ culture dishes, then were seeded in 96 -well plates $(200 \mu \mathrm{L}$; cell density $5 \times 10^{5}$ cells $/ \mathrm{mL}$ ). After plating for 1 day, the medium was replaced with fresh DMEM medium 
supplemented with $10 \%$ FBS with or without the indicated compound (final concentration $5 \mu \mathrm{M}$ ), then the cells were incubated for $24 \mathrm{~h}$, after which the medium was replaced with $200 \mu \mathrm{L}$ assay buffer (PBS containing $5.5 \mathrm{mM}$ D-glucose, $0.3 \mathrm{mM}$ sodium pyruvate, $25 \mathrm{mM}$ sodium bicarbonate, and $1.5 \mu \mathrm{M}$ zinc sulfate) containing $2 \mu \mathrm{M}$ qf-A $\beta(1-7) \mathrm{C}$ and the cells incubated for $1.5 \mathrm{~h}$. To measure $\mathrm{A} \beta$-degrading activity, $150 \mu \mathrm{L}$ of the assay buffer was taken for fluorescence measurement on a SpectraMax Gemini EM (Molecular Devices, USA) with excitation at $346 \mathrm{~nm}$ and emission at $442 \mathrm{~nm}$. When the donor is excited, the energy is transferred to the quencher and no fluorescence is emitted. If this peptide is cleaved by NEP or IDE, the quencher can no longer quench the fluorescence, so strong fluorescence emission is detected.

$A \beta$-degrading activity assay using qf-A $\beta(12-16) A A C$ as substrate. qf-A $\beta(12-16) A A C$ (sequence VHHQKAAC with Alexa-350 and Dabcyl attached to Cys sidechain and the N-terminus, respectively) was synthesized according to the previously published procedure ${ }^{28}$ and dissolved as a $2 \mathrm{mM}$ stock solution in DMSO. SH-SY5Y cells were seeded in 24 -well plates $\left(450 \mu \mathrm{L}\right.$; cell density $1 \times 10^{6}$ cells $\left./ \mathrm{mL}\right)$ in DMEM plus $10 \%$ FBS and treated with the compounds as above for $12 \mathrm{~h}$, then the medium was replaced with assay buffer containing $4 \mu \mathrm{M}$ qf-A $\beta(12-16) A A C$ and the cells incubated for $1 \mathrm{~h}$. To measure $A \beta$-degrading activity, $150 \mu \mathrm{L}$ of the buffer was assayed for fluorescence as above.

Protease inhibition assay. SH-SY5Y cells seeded in 12 -well plates $\left(1 \mathrm{~mL}\right.$; cell density $1 \times 10^{6}$ cells $\left./ \mathrm{mL}\right)$ were incubated with vehicle or compound 8 for $12 \mathrm{~h}$, then the medium was replaced with $400 \mu \mathrm{L}$ of assay buffer containing $50 \mu \mathrm{M}$ thiorphan (Sigma) and the cells incubated for $30 \mathrm{~min}$, then $100 \mu \mathrm{L}$ of the buffer was removed and mixed with $0.8 \mu \mathrm{L}$ of $2 \mathrm{mM}$ qf-A $\beta(12-16) \mathrm{AAC}$, and the mixture returned to the well. The cells were then incubated for $1 \mathrm{~h}$ and $150 \mu \mathrm{L}$ of the supernatant taken for fluorescence measurement as above.

NEP western blotting. SH-SY5Y cells were seeded on $100-\mathrm{mm}$ culture dish at a cell density of $5.5 \times 10^{6}$ cells/ $\mathrm{mL}$ (about $60-70 \%$ confluent) in DMEM/F12 medium with 1\% FBS and the medium volume of $10 \mathrm{~mL}$. Retinoic acid (RA) was added the day after plating at a final concentration of $10 \mu \mathrm{M}$ in DMEM/F12 medium with $1 \%$ FBS. The medium was replaced with fresh DMEM/F12 medium containing $10 \mu \mathrm{M}$ RA every two days. After 5 days in the presence of RA, cells were ready for NEP expression measurements. The culture medium was replaced with fresh DMEM/F12 medium supplemented with $1 \%$ FBS and $5 \mu \mathrm{M}$ of the indicated compounds or vehicle, and the cells were incubated for $24 \mathrm{~h}$. Cells were then washed out of the dishes with PBS and centrifuged at $200 \mathrm{~g}$ for $5 \mathrm{~min}$ at $4{ }^{\circ} \mathrm{C}$, and the cell pellets were collected for membrane extraction. The membrane fractions were extracted from the cell pellets using the Mem-PER Plus Membrane Protein Extraction Kit (Thermo Scientific, USA). After quantifying the protein content of the membrane fractions using the BCA kit (Thermo Scientific, USA), 10 $\mu \mathrm{g}$ of protein was resolved on an $8 \%$ Bis-Tris gel by SDS-PAGE and transferred to a nitrocellulose membrane (PerkinElmer, USA). The membrane was then blocked in $5 \%$ nonfat dry milk (Fonterra, New Zealand), $0.1 \%$ Tween 20, $50 \mathrm{mM}$ Tris, $15 \mathrm{mM} \mathrm{NaCl}, \mathrm{pH} 7.5$ for $1 \mathrm{~h}$ at $4{ }^{\circ} \mathrm{C}$, and incubated overnight at $4{ }^{\circ} \mathrm{C}$ with mouse monoclonal anti-human NEP antibody (MAB11821, R\&D Systems, USA) and mouse monoclonal anti-glyceraldehyde 3-phosphate dehydrogenase (GAPDH) antibody (Proteintech, USA) at a dilution of 1:5000 in the blocking buffer. After three washes with $0.1 \%$ Tween $20,50 \mathrm{mM}$ Tris, and $15 \mathrm{mM} \mathrm{NaCl}$ (pH 7.5), the membrane was incubated for $2 \mathrm{~h}$ at $4{ }^{\circ} \mathrm{C}$ with horseradish peroxidase-conjugated anti-mouse IgG antibodies (R\&D Systems, USA) at a dilution of 1:1000 in the blocking buffer.

To compare the mouse brain NEP protein levels, the cortex pellet from formic acid extraction was collected and washed twice with PBS. The membrane fractions of the tissue pellets were extracted by stirring with $400 \mu \mathrm{L}$ of the buffer $(50 \mathrm{mM}$ Tris, $150 \mathrm{mM} \mathrm{NaCl}, 5 \mathrm{mM}$ EDTA, $0.5 \%$ Triton X-100, $0.5 \%$ sodium deoxycholate, $\mathrm{pH} 8$ ) for $40 \mathrm{~min}$ at $4{ }^{\circ} \mathrm{C}$. After stirring, the solution was centrifuged at $20000 \mathrm{~g}$ for $15 \mathrm{~min}$ at $4{ }^{\circ} \mathrm{C}$. The supernatant containing extracted membrane proteins was collected and concentrated by Amicon Ultra- 0.5 (cutoff $30 \mathrm{kDa}$, Millipore, USA). After quantifying the protein content using the BCA kit (Thermo Scientific, USA), $12 \mu \mathrm{g}$ of protein was analyzed by SDS-PAGE and immunoblotted as described above, substituting rat monoclonal anti-mouse NEP antibody (MAB1126, R\&D Systems, USA) (1:500 dilution) as primary antibody and horseradish peroxidase-conjugated anti-rat IgG antibodies (R\&D Systems, USA) (1:1000 dilution) as secondary antibody.

Animal experiments. All animal experiments were approved by the Institutional Animal Care and Use Committee of the Academia Sinica. The mice were kept in individually ventilated cages (IVC) on a 12:12 h light:dark cycle with food and tap water freely available.

To analyze brain $\mathrm{A} \beta$ content, $\mathrm{APP}_{\text {swe }} / \mathrm{PS}_{1} \mathrm{dE}_{9}$ transgenic mice (B6C3-Tg $\left.\left(\mathrm{APP}_{\text {swe }}, \mathrm{PSEN}_{1} \mathrm{dE}_{9}\right) 85 \mathrm{Dbo} / \mathrm{Mmjax}\right)$ were purchased from Jackson Laboratories (USA) and bred and genotyped as described on the Jackson website ${ }^{44,45}$. Five $\mathrm{APP}_{\text {swe }} / \mathrm{PS}_{1} \mathrm{dE}_{9}$ mice were fed orally with vehicle and five with compound $7(10 \mathrm{mg} / \mathrm{kg} /$ day $)$ six times a week by gavage from the age of 4.5-5.5 months for 6.5 months. In the first 3 months, the compound was dissolved at a concentration of $1 \mathrm{mg} / \mathrm{mL}$ in $2 \%$ carboxymethylcellulose, after which the solvent was changed to the mixture of PEG 600 and Cremophor EL (v/v ratio 2:1) containing 1\% methylcellulose for better solubility. The control five $\mathrm{APP}_{\text {swe }} / \mathrm{PS}_{1} \mathrm{dE}_{9}$ mice were fed the corresponding solvent.

In the short-term treatment test, compound 1,7 , or 8 was dissolved at a concentration of $1 \mathrm{mg} / \mathrm{mL}$ in the mixture of PEG 600 and Cremophor EL (v/v ratio 2:1) containing 1\% methylcellulose, then the compound or solvent was fed to 5-month-old $\mathrm{B} 6 \mathrm{C} 3$ mice (non-transgenic female littermates of the $\mathrm{APP}_{\text {swe }} / \mathrm{PS}_{1} \mathrm{dE}_{9} / \mathrm{B} 6 \mathrm{C} 3$ matings) $(10 \mathrm{mg} / \mathrm{kg} /$ day, five mice per group) by gavage daily for 7 days. The mice were sacrificed $1 \mathrm{~h}$ after the last feed. The brains were removed, and the cortical and hippocampal tissues were dissected out and placed in Eppendorf tubes, immediately frozen in liquid nitrogen, and stored at $-80^{\circ} \mathrm{C}$ until use.

To analyze $\mathrm{A} \beta$ plaque in the brain, $\mathrm{APP}_{\text {swe }} / \mathrm{PS}_{1} \mathrm{dE}_{9}$ transgenic mice were fed orally with vehicle $(\mathrm{n}=3$, male mice $)$ or compound $8(\mathrm{n}=6$, male mice $)$ six times a week $(10 \mathrm{mg} / \mathrm{kg} /$ day $)$ by gavage from the age of 3 months 
to 11 months. Then, the mice were euthanized by cervical dislocation. These mice were perfused transcardially with PBS (136.89 mM NaCl, $2.68 \mathrm{mM} \mathrm{KCl}, 1.62 \mathrm{mM} \mathrm{KH}_{2} \mathrm{PO}_{4}$, and $10.14 \mathrm{mM} \mathrm{Na}_{2} \mathrm{HPO}_{4}, \mathrm{pH}$ 7.4) buffer, and post-fixed in $4 \%$ paraformaldehyde (PFA)/PBS solution with gentle shaking at room temperature for 3 days. After post-fixation, brain samples were washed with PBS buffer and preserved in $70 \%$ ethanol/water solution.

Protein extraction for $\boldsymbol{A} \beta$ ELISA. Half of the frozen cortical and hippocampal tissue samples were homogenized in $1 \mathrm{~mL}$ tapered tissue grinders in $400 \mu \mathrm{L}$ of ice-cold TBS buffer $(50 \mathrm{mM}$ Tris, $150 \mathrm{mM} \mathrm{NaCl}, 2 \mathrm{mM}$ EDTA, $\mathrm{pH}$ 7.4) containing a protease inhibitor cocktail (1:100 dilution) (P8340, Sigma), then the homogenates were transferred to $1.5 \mathrm{~mL}$ Eppendorf tubes and centrifuged at $20000 \mathrm{~g}$ for $20 \mathrm{~min}$ at $4{ }^{\circ} \mathrm{C}$. The supernatant contained soluble $A \beta$, whereas the TBS-insoluble pellet contained insoluble $A \beta$. The TBS-insoluble pellet was suspended in $70 \%$ formic acid, sonicated for $1 \mathrm{~min}$, then centrifuged at $20000 \mathrm{~g}$ for $20 \mathrm{~min}$ at $4{ }^{\circ} \mathrm{C}$. The final supernatant containing the solubilized $\mathrm{A} \beta$ was removed and neutralized with 20 volumes of $1 \mathrm{M}$ Tris base. The protein concentration of samples containing the solubilized "insoluble" $\mathrm{A} \beta$ was quantified using the Bradford protein assay (Bio-Rad \#500-0006).

A $\beta 40$ and A $\beta 42$ ELISA. The samples containing the solubilized "insoluble" A $\beta$ were diluted 800 fold before ELISA quantification, then $A \beta 40$ and $A \beta 42$ were quantified using human $A \beta 40$ and $A \beta 42$ ELISA kits (Invitrogen, Catalog no. KHB3481 and KHB3441) according to the manufacturer's protocol, measuring the absorbance at $450 \mathrm{~nm}$ on a SpectraMax ${ }^{\circledR}$ Paradigm ${ }^{\circledR}$ Multi-Mode reader (Beckman/Molecular Devices, USA). All samples were analyzed in triplicate.

Real-time PCR Analysis. Half of the frozen cortical and hippocampal tissues from $\mathrm{APP}_{\text {swe }} / \mathrm{PS}_{1} \mathrm{dE}_{9}$ transgenic mice (long-term treatment, $\mathrm{n}=5$ for each group) and half of the whole brain from B6C3 mice (short-term treatment, $\mathrm{n}=5$ for each group) was immersed in TRIzol ${ }^{\circledR}$ reagent (Invitrogen) for $1 \mathrm{~h}$, then homogenized as above using a tapered tissue grinder. Total RNA was purified using a TRIzol ${ }^{\circledR}$ Plus Reagent RNA Purification Kit (Invitrogen) according to the manufacturer's protocol. All RNA samples were then treated with DNase I to remove any residual DNA. Reverse transcription of $5 \mu \mathrm{g}$ of RNA was carried out using the Maxima First Strand cDNA Synthesis Kit (Thermo Scientific, USA), with $\beta$-actin as the reference gene. The sequences of the primers used were: (a) NEP, forward, TCCTGACTATCATAGCGGTGAC; reverse, GACGTTGCGTTTCAACCAGC, (b) $\beta$-actin, forward, GGCTGTATTCCCCTCCATCG; reverse, CCAGTTGGTAACAATGCCATGT. Quantitative PCR was performed on $2 \mu \mathrm{g}$ of cDNA in a total volume of $20 \mu \mathrm{L}$ in a Light Cycler 480 II (Roche) using a Multicolour PCR detection system and SYBR Green. The thermal cycler conditions were activation at $95^{\circ} \mathrm{C}$ for $5 \mathrm{~min}$, followed by 45 cycles of amplification containing three steps: (1) denaturation at $95^{\circ} \mathrm{C}$ for $10 \mathrm{sec}$; (2) annealing at $60^{\circ} \mathrm{C}$ for $10 \mathrm{sec}$, and (3) extension at $72^{\circ} \mathrm{C}$ for $10 \mathrm{sec}$. NEP mRNA levels in each sample were normalized to $\beta$-actin mRNA levels. All samples were analyzed in triplicate.

Thioflavin S (ThS) staining. PFA-fixed left hemispheres were dehydrated by a semi-enclosed benchtop tissue processor (Leica TP1020, Germany). Paraffin blocks containing the dehydrated samples were prepared by paraffin embedding module (Leica EG1150H). Coronal sections with $3 \mu \mathrm{m}$ thickness were cut on a rotary microtome (Leica RM2235, Germany). Paraffin slides were deparaffinized and rehydrated with xylene, absolute ethanol, $95 \%$ ethanol, $70 \%$ ethanol, and water, sequentially. Rehydrated slides were applied with $1 \%(w / v)$ thioflavin S solution for $10 \mathrm{~min}$ at room temperature (protected from light). The slides were washed with $80 \%$ ethanol and water to remove excess fluorochrome and to facilitate visualization. Thioflavin S-positive signals were then visualized by a fluorescence microscope. The plaque number and plaque area were analyzed by Image ${ }^{46}$.

DNA methylation analysis by bisulfite genomic sequencing. Genomic DNAs from the N2a cells with and without the treatment of compounds 1, 7, and 8 were prepared using a QIAamp DNA Mini Kit (Qiagen $\mathrm{GmbH}$, Hilden, Germany). The bisulfite modification method was employed to determine the methylation status of cytosine residues in the genomic DNA ${ }^{47}$. Bisulfite modification of the genomic DNA samples was achieved using an EpiTect Bisulfite Kit (Qiagen, Germany). Nested PCR was used to amplify the upper strand of the bisulfite-modified DNA segment that encompasses the promoter the NEP gene. The first round of PCR was performed using the forward primer, $5^{\prime}$-AAGTTTTTTTGGGAAGGGTAAGGTGGG-3' , and the reverse primer, 5'-CCRCCCRCTCTATCCTCCTATTACC-3', for the modified sequences. The second round of PCR was performed using the forward primer, $5^{\prime}$-AATTTTTAGGTTATTTAGGGAATTGT- $3^{\prime}$, and the reverse primer, $5^{\prime}$-AAACRACTAAACAAACACATCCC- $3^{\prime}$ for the modified sequences ${ }^{37}$, which amplify the promoter region of the NEP gene. The PCR-amplified DNA segments were cloned into the pGEM-T Easy vector (Promega Corp., Madison, USA). Ten clones from the PCR-amplified product were selected for each sample and their sequences determined in order to estimate the incidence of methylation at the CG dinucleotides in the promoter region of the NEP gene. In total, $39 \mathrm{CpG}$ sites were analyzed.

Ethics statement. The animal experiments were approved by the Institutional Animal Care and Use Committee of Academia Sinica. The methods were carried out in accordance with the approved guidelines.

\section{References}

1. Lannfelt, L. et al. Perspectives on future Alzheimer therapies: amyloid-beta protofibrils - a new target for immunotherapy with BAN2401 in Alzheimer's disease. Alzheimers Res. Ther. 6, 16 (2014).

2. Moreth, J., Mavoungou, C. \& Schindowski, K. Passive anti-amyloid immunotherapy in Alzheimer's disease: What are the most promising targets? Immun. Ageing 10, 18 (2013).

3. Iwata, N., Higuchi, M. \& Saido, T. C. Metabolism of amyloid-b peptide and Alzheimer's disease. Pharmacol. Therapeut. 108, 129-148 (2005). 
4. Wang, D. S., Iwata, N., Hama, E., Saido, T. C. \& Dickson, D. W. Oxidized neprilysin in aging and Alzheimer's disease brains. Biochem. Biophys. Res. Commun. 310, 236-241 (2003).

5. Hellstrom-Lindahl, E., Ravid, R. \& Nordberg, A. Age-dependent decline of neprilysin in Alzheimer's disease and normal brain: inverse correlation with A beta levels. Neurobiol. Aging 29, 210-221 (2008).

6. Yasojima, K., McGeer, E. G. \& McGeer, P. L. Relationship between beta amyloid peptide generating molecules and neprilysin in Alzheimer disease and normal brain. Brain Res. 919, 115-121 (2001).

7. Caccamo, A., Oddo, S., Sugarman, M. C., Akbari, Y. \& LaFerla, F. A. Age- and region-dependent alterations in Ab-degrading enzymes: implications for Ab-induced disorders. Neurobiol. Aging 26, 645-654 (2005).

8. Iwata, N., Takaki, Y., Fukami, S., Tsubuki, S. \& Saido, T. C. Region-specific reduction of A beta-degrading endopeptidase, neprilysin, in mouse hippocampus upon aging. J. Neurosci. Res. 70, 493-500 (2002).

9. Iwata, N. et al. Metabolic regulation of brain Ab by neprilysin. Science 292, 1550-1552 (2001).

10. Liu, Y. et al. Circulating neprilysin clears brain amyloid. Mol. Cell. Neurosci. 45, 101-107 (2010).

11. Guan, H. et al. Peripherally expressed neprilysin reduces brain amyloid burden: a novel approach for treating Alzheimer's disease. J. Neurosci. Res. 87, 1462-1473 (2009).

12. Park, M. H. et al. Recombinant soluble neprilysin reduces amyloid-beta accumulation and improves memory impairment in Alzheimer's disease mice. Brain Res. 1529, 113-124 (2013).

13. El-Amouri, S. S. et al. Neprilysin: an enzyme candidate to slow the progression of Alzheimer's disease. Am. J. Pathol. 172, 1342-1354 (2008).

14. Hemming, M. L. et al. Reducing amyloid plaque burden via ex vivo gene delivery of an A $\beta$-degrading protease: A novel therapeutic approach to Alzheimer disease. PLoS Med. 4, e262 (2007).

15. Blurton-Jones, M. et al. Neural stem cells genetically-modified to express neprilysin reduce pathology in Alzheimer transgenic models. Stem Cell Res. Ther. 5, 46 (2014).

16. Ayoub, S. \& Melzig, M. F. Influence of selected natural products on neutral endopeptidase activity and $\beta$-amyloid production in SKN-SH cells. Pharmaceut. Biol. 46, 425-432 (2008).

17. Eisele, Y. S. et al. Gleevec increases levels of the amyloid precursor protein intracellular domain and of the amyloid- $\beta$-degrading enzyme neprilysin. Mol. Biol. Cell 18, 3591-3600 (2007).

18. Klein, C. et al. The neuroprotector kynurenic acid increases neuronal cell survival through neprilysin induction. Neuropharmacology 70, 254-260 (2013).

19. Chandra, V. et al. Incidence of Alzheimer's disease in a rural community in India: the Indo-US study. Neurology 57, 985-989 (2001).

20. Ganguli, M. et al. Apolipoprotein E polymorphism and Alzheimer disease: The Indo-US cross-national dementia study. Arch. Neurol. 57, 824-830 (2000).

21. Brondino, N. et al. Curcumin as a therapeutic agent in dementia: A mini systematic review of human studies. Sci. World J. 2014, 174282 (2014).

22. Aggarwal, B. B., Sundaram, C., Malani, N. \& Ichikawa, H. Curcumin: the Indian solid gold. Adv. Exp. Med. Biol. 595, 1-75 (2007).

23. Liao, K. K. et al. Curcuminoids promote neurite outgrowth in PC12 cells through MAPK/ERK- and PKC-dependent pathways. J. Agric. Food Chem. 60, 433-443 (2012).

24. Lim, G. P. et al. The curry spice curcumin reduces oxidative damage and amyloid pathology in an Alzheimer transgenic mouse. J. Neurosci. 21, 8370-8377 (2001).

25. Wang, P. et al. Mechanisms and effects of curcumin on spatial learning and memory improvement in APPswe/PS1dE9 mice. J. Neurosci. Res. 92, 218-231 (2014).

26. Ahmed, T., Enam, S. A. \& Gilani, A. H. Curcuminoids enhance memory in an amyloid-infused rat model of Alzheimer's disease. Neuroscience 169, 1296-1306 (2010).

27. Endo, H., Nikaido, Y., Nakadate, M., Ise, S. \& Konno, H. Structure activity relationship study of curcumin analogues toward the amyloid-beta aggregation inhibitor. Bioorg. Med. Chem. Lett. 24, 5621-5626 (2014).

28. Chen, P. T. et al. A highly sensitive peptide substrate for detecting two Ab-degrading enzymes: neprilysin and insulin-degrading enzyme. J. Neurosci. Methods 190, 57-62 (2010).

29. Chen, P. T. et al. Design of peptide substrate for sensitively and specifically detecting two A $\beta$-degrading enzymes: neprilysin and angiotensin-converting enzyme. PLoS One 11, e0153360 (2016).

30. Li, W. et al. Structure elucidation and NMR assignments for curcuminoids from the rhizomes of Curcuma longa. Magn. Reson. Chem. 47, 902-908 (2009).

31. Wei, Q. Y., Chen, W. F., Zhou, B., Yang, L. \& Liu, Z. L. Inhibition of lipid peroxidation and protein oxidation in rat liver mitochondria by curcumin and its analogues. Biochim. Biophys. Acta 1760, 70-77 (2006).

32. Begum, A. N. et al. Curcumin structure-function, bioavailability, and efficacy in models of neuroinflammation and Alzheimer's disease. J. Pharmacol. Exp. Ther. 326, 196-208 (2008).

33. Yang, F. et al. Curcumin inhibits formation of amyloid beta oligomers and fibrils, binds plaques, and reduces amyloid in vivo. J. Biol. Chem. 280, 5892-5901 (2005).

34. Yasojima, K., McGeer, E. G. \& McGeer, P. L. Relationship between beta amyloid peptide generating molecules and neprilysin in Alzheimer disease and normal brain. Brain Res. 919, 115-121 (2001).

35. Uematsu, F., Takahashi, M., Yoshida, M., Igarashi, M. \& Nakae, D. Methylation of neutral endopeptidase 24.11 promoter in rat hepatocellular carcinoma. Cancer Sci 97, 611-617 (2006).

36. Usmani, B. A. et al. Methylation of the neutral endopeptidase gene promoter in human prostate cancers. Clin. Cancer Res. 6, $1664-1670(2000)$.

37. Deng, Y. et al. Curcumin inhibits the AKT/NF-kappaB signaling via CpG demethylation of the promoter and restoration of NEP in the N2a cell line. AAPS J 16, 649-657 (2014).

38. Lim, C. S. \& Alkon, D. L. PKCepsilon promotes HuD-mediated neprilysin mRNA stability and enhances neprilysin-induced Abeta degradation in brain neurons. PLoS One 9, e97756 (2014).

39. Kakiya, N. et al. Cell surface expression of the major amyloid-beta peptide (Abeta)-degrading enzyme, neprilysin, depends on phosphorylation by mitogen-activated protein kinase/extracellular signal-regulated kinase kinase (MEK) and dephosphorylation by protein phosphatase 1a. J. Biol. Chem. 287, 29362-29372 (2012).

40. Saito, T. et al. Somatostatin regulates brain amyloid b peptide Ab42 through modulation of proteolytic degradation. Nat. Med. 11, 434-439 (2005)

41. Khanna, S. et al. Neuroprotective and antiinflammatory properties of a novel demethylated curcuminoid. Antioxid. Redox Signal. 11, 449-468 (2009).

42. Chen, W. F., Deng, S. L., Zhou, B., Yang, L. \& Liu, Z. L. Curcumin and its analogues as potent inhibitors of low density lipoprotein oxidation: $\mathrm{H}$-atom abstraction from the phenolic groups and possible involvement of the 4-hydroxy-3-methoxyphenyl groups. Free Radic. Biol. Med. 40, 526-535 (2006).

43. Venkateswarlu, S., Ramachandra, M. S. \& Subbaraju, G. V. Synthesis and biological evaluation of polyhydroxycurcuminoids. Bioorg. Med. Chem. 13, 6374-6380 (2005).

44. Borchelt, D. R. et al. Familial Alzheimer's disease-linked presenilin 1 variants elevate Abeta1-42/1-40 ratio in vitro and in vivo. Neuron 17, 1005-1013 (1996). 
45. Jankowsky, J. L. et al. Co-expression of multiple transgenes in mouse CNS: a comparison of strategies. Biomol. Eng. 17, 157-165 (2001).

46. Schneider, C. A., Rasband, W. S. \& Eliceiri, K. W. NIH Image to ImageJ: 25 years of image analysis. Nature Methods 9, 671-675 (2012).

47. Frommer, M. et al. A genomic sequencing protocol that yields a positive display of 5-methylcytosine residues in individual DNA strands. Proc. Natl. Acad. Sci. USA 89, 1827-1831 (1992).

\section{Acknowledgements}

Real-time PCR and A $\beta$ ELISA were performed in the Biophysics Core Facility with the help from Dr. Meng-Ru Ho. Sample preparation for tissue staining was performed in the pathological core facility and mice were kept in the animal facility. All these facilities were in the Institute of Biological Chemistry, Academia Sinica.

\section{Author Contributions}

P.-T.C., Z.-t.C. and L.-C.Y. performed the experiments; W.-C.H. provided materials; R.P.-Y.C. designed the study; P.-T.C. and R.P.-Y.C. analyzed the data and wrote the paper.

\section{Additional Information}

Supplementary information accompanies this paper at http://www.nature.com/srep

Competing financial interests: There is potential competing financial interests. One US patent (US 9,074,238) has been granted.

How to cite this article: Chen, P.-T. et al. Polyhydroxycurcuminoids but not curcumin upregulate neprilysin and can be applied to the prevention of Alzheimer's disease. Sci. Rep. 6, 29760; doi: 10.1038/srep29760 (2016).

(c) (i) This work is licensed under a Creative Commons Attribution 4.0 International License. The images or other third party material in this article are included in the article's Creative Commons license, unless indicated otherwise in the credit line; if the material is not included under the Creative Commons license, users will need to obtain permission from the license holder to reproduce the material. To view a copy of this license, visit http://creativecommons.org/licenses/by/4.0/ 